\title{
The Evaluation of the Acceptance and Intention of Using the Healthy Travel Mobile Guide System
}

\author{
Meichiao Lai \\ Department of Logistics Management \\ Fuzhou University of International Studies and Trade \\ Fuzhou, China
}

\author{
Dan Liu \\ Department of Logistics Management \\ Fuzhou University of International Studies and Trade \\ Fuzhou, China
}

\author{
Lee Yang \\ Department of Logistics Management \\ Fuzhou University of International Studies and Trade \\ Fuzhou, China
}

\begin{abstract}
This paper aims to evaluate the acceptance and intention of college students to use the mobile guide system by the Unified Theory of Acceptance and Use of Technology (UTAUT) model. Questionnaires were administered to understand the context of use, the factors contributing to the user's willingness to use this system and the extent of the impact. It was found that the mean value of the factor of performance expectations is $0.815(5.85 / 7=0.835)$, indicating $83.5 \%$ of the population agreed that using the mobile guide system helps them to obtain information on the health travel sites more easily and quickly. The participants also show favorable attitude toward the use of the mobile guide system in improving the quality of tourism. However, only $78.1 \%$ of the population $(5.47 / 7=0.781)$ shows the willingness to use the mobile guide system, suggesting that the willingness is lower than the awareness of its importance and value. Secondly, this study found that among the three factors contributing to the willingness of using the mobile guide system, the social impact is the most important, followed by social influence, while effort consuming expectations is the least. It means that if the participant's relatives or friends are supportive of using the mobile guide system, his/her intention to use will be relatively high. The participant's awareness of the importance, convenience and benefits of the mobile guide system also contributes to his/her willingness to use. Moreover, if the interface of the system is user-friendly, Internet speed is fast enough and running smoothly, the intention of using the system will also be higher.
\end{abstract}

Keywords-healthy travel mobile guide system; unified theory of acceptance and use of technology(utaut); intention to use

\section{INTRODUCTION}

With the realization of historical spanning from shortagetype tourism developing country to preliminary well-off tourism country, the Chinese tourism has turned out to be popular consumption among ordinary people from the minority luxuries. It is now the important contents of people's daily life and participates in creating of job opportunities and employment. People's demand for tourism is developing towards diversified and characteristic features, which also propose new requirements on diversified leisure product, modern consumption mode, convenient public tourism traffic service and excellent tourism environment (Office of Fujian Tourism Bureau Zhao Hongwei).

Among the seven measures for accelerating tourism transformation and upgrading that are clearly proposed in the main contents of Fujian People's Government Implementation Suggestion on Further Deepening Tourism Reform and Development, the fourth measure is to promote the melting of tourism and informatization. We make "Internet + Tourism" plan to form the "Internet + Tourism" - oriented diversified portable tourism APP according to the tourism element features and new generation information technologies as cloud computing, Internet of Things, and big data. And it has always been our key developing aspect to strengthen planning and implementing of provincial smart tourism development, systematically enhance the tourism management, service, and marketing levels, and continuously engaging in trial construction for smart tourism city, smart resort, and smart hotel. It can be seen that the tourism career has been the key developing point of our provincial government these years (Office of Fujin Tourism Bureau Zhao Hongwei). However, the healthy tourism is a kind of comprehensive career. It must combine with tourism, healthy and medical care industry, scenic sites, entertainment career, specialty industry, and ecological management, etc. The tourism ecology and healthy tourism career have great potential of development. And correspondingly, the quality enhancement of tourism ecology and healthy tourism related service is in urgency. This is the motives of this study.

Therefore, the purpose of this plan is to take the Unified Theory of Acceptance and User of Technology to discuss the college students' acceptance to healthy travel mobile guide system, intention to use, factors affecting their intention to use the mobile guide system, affecting degree, and practical use status of the mobile guide system. 


\section{LITERATURE DISCUSSION}

\section{A. Mobile Guide System}

The "user" may get the updated surrounding information in real-time by cable network and wifi without being limited by time or place. This is the concept called "Omnipresent Network Environment", or "U-environment". Based on this, when tourists uses U-environment inside the part zone, the employer may sense the using records of the user inside park zone via back-end management, such as: consumer behavior, purchasing preference, real-time tour description, thus to provide customized value-added services. This is called mobile guide system (Chen Hongbin et.al. 2012).

Therefore, complying with the vigorous information development and the uprising of smart mobile devices, such as PDA, smart phone, Table PC, as well as the development of positioning system and GIS, the advantages in space, moving, and real-time data presentation show up, which helps the emerging of mobile guide system, which is featured in light and portable individual interaction guide and convenient operating interface. Besides, omnipresent U-environment, which is based on wifi, could provide the tourists with the realtime information and allow them choose routes by themselves according to the travel plan and voice positioning guide. It is no longer the traditional guide mode, but turns out to be map with illustrations and characters, or group description, to allow travel by themselves and realize deep guide experience.

\section{B. Intention}

The so called act intention refers to the subjective probability judgment of individual for taking a certain act. It reflects the intention of individual to take a certain act. The theory considers that, the most direct factor deciding an individual taking a certain act is behavioral intention. It also considers that all factors that may affect the act are representation of behavioral intention affecting act indirectly. Lots of researches point out that, under given conditions; the behavioral intention is the best way predicting individual behavior. And the behavioral intention and behavior have high correlation (Ajzen, 1991).

\section{Factors Affecting Intention}

Looking back the domestic essays about UTAUT, Zhang Hongchang (Min 93) Research on Staff Acceptance of Enterprise Internal Network - Taking Sinosteel for Instance, the research takes UTAUT as the basis to modify the scale from the view of big scale traditional industry, and performs sampling layer by layer to carry out questionnaire to individual companies; the second is Cai Bingru (Min 93) who adopts UTAUT to discusses the factors affecting life insurance businessman taking mobile business system in the study of factors affecting life insurance businessman taking mobile life insurance system. However, in terms of mobile guide system acceptance, it lacks of relative research.

Performance expectancy, effort expectancy, and social influence are the factors affecting behavior intention in UTAUT model; and the facilitating conditions and behavior intention are the factors affecting use behavior. The above affecting relation would be affected by four disturbance variables of gender, age, experience, and voluntariness of use. The aspects and disturbance variable meanings in UTAUT model are described as follows.

- Performance expectancy: the individual use of mobile guide is helpful for health, and is able to enhance individual travel confidence, traffic and accommodation convenience, thus to realize selfdemand-satisfaction and increase confidence. Performance expectancy would be affected by both gender and age (Venkatesh \& Morris, 2000).

- Effort expectancy: difficulty degree of using the system. For behavior intention, it could be affected by gender, age, and experience. Venkatesh \& Morris (2000) also pointed out the female could have higher effort expectancy than male.

- Social influence: the degree that the users consider the key persons who should use the mobile guide system. It is affected by disturbance variables as gender, age, experience, and voluntariness. Venkatesh and Davis (2000) pointed out that the social influence is the deciding factor of intention. He Weijia (2004) considered that mouth-to-mouth spreading is the most important and reliable information source for college students using mobile guide system. In aspect of gender, female would be easier to accept other's suggestion. But the effect of social influence could gradually reduce with the increase of experience (Venkatesh \& Morris, 2000).

- Facilitating conditions: user's capability to understand relative resource or technical aspect support; in practical use, condition facilitating would be affected by age and experience, and other disturbance variables.

\section{RESEARCH METHOD}

\section{A. Research Architecture}

This plan is to apply UTAUT to discuss college students' acceptance to mobile guide mode, intention to use, and verify the factors affecting the intention to use, affecting degree, and practical use status. The research architecture is as follow "Fig. $1 ”$. 


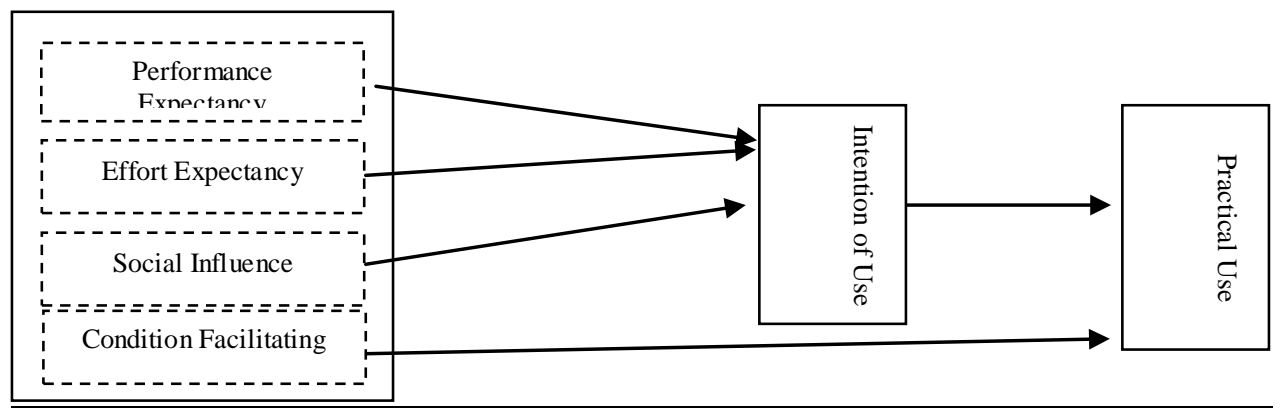

Fig. 1. Research Architecture of Intention to Use Healthy Travel Mobile Guide System

This research uses the aspect and affecting factor design scale of Unified Theory of Acceptance and Use of Technology as the research instrument, adopts questionnaires to collect data, and adopts SPSS for Windows 17.0 statistic software to perform data analysis. The methods include: descriptive statistic analysis, independent sample T-Test, correlation analysis, multiple regression analysis, etc.

\section{B. Study Hypotheses}

According to the above research mode, the hypotheses of this research are respectively stipulated as follows:

- Hypothesis 1: the performance expectancy of college students using healthy mobile guide system would affect their intention to use.

- Hypothesis 2: the effort expectancy of college students using healthy mobile guide system would affect their intention to use.

- Hypothesis 3: the social influence of college students using healthy mobile guide system would affect their intention to use.

\section{Research Object and Method}

It is performed by the mode of answering questionnaire on Internet. The main objects are students, including all the students upgrading from junior college to university, undergraduates, and part of the teachers and tutors, etc.

\section{RESEARCH RESULTS}

The research result is divided into three parts: the first part is population variable, including gender, age, education background, occupational category, income, reading travel information, reading medical care information, and weekly surfing-on-line times; the second part is the data analysis on students' intention of using the travel mobile guide system, including reliability analysis, times allocation table, description statistics and relative analysis; and the final part is multiple regression for verifying three hypothesis.

\section{A. Population Variable}

In this research, 500 electronic questionnaires were sent to the students of this university via Internet, 349 were re- collected, including 318 effectively answered questionnaires. The effective re-collecting rate is $73.6 \%$. According to the recollected questionnaires, the author performs SPSS 17.0 version analysis on the study samples. The population variable distribution status is as follows: 36 male answered questionnaires, occupying $11.3 \%$ of the total samples; 282 female answered questionnaires, occupying $88.7 \%$ of the total samples; 198 questionnaires from students under 19 years old, occupying 30.8\%; 102 questionnaires from students between 20-29 years old, occupying $67.6 \%$; amount of students surfing on line for over 7 times every week is of the majority, reaching 232 , occupying $73.0 \%$; amount of students majoring in finance management is of the majority, reaching 70 , occupying $22.0 \%$, and the second is accounting, reaching 60, occupying $18.9 \%$, and the next is engineering management, reaching 51, occupying $16.0 \%$. The amount of students frequently reading healthy travel information is of the majority, reaching 166 , occupying 52.2\%; and the amount rarely reading reaches 144 , occupying $45.3 \%$.

\section{B. Aspect Reliability}

Reliabilities of all affecting aspects are between 0.8-0.9 (higher than 0.7), which means that all the five aspects are reliable. Please see "Table I".

TABLE I. RELIABILITIES OF All ASPECTS

\begin{tabular}{llll}
\hline S/N & \multicolumn{1}{c}{ Name of Aspects } & $\begin{array}{c}\text { Items } \\
\text { Number }\end{array}$ & $\begin{array}{c}\text { Cronbach's } \\
\text { Alpha }\end{array}$ \\
\hline 1 & Performance Expectancy & 4 & 0.911 \\
2 & Effort Expectancy & 4 & 0.810 \\
3 & Condition Facilitating & 5 & 0.791 \\
4 & Social Influence & 4 & 0.906 \\
5 & Intention of Use & 3 & 0.909 \\
\hline$(\mathrm{N}=318)$ & &
\end{tabular}

\section{Description and Statistics of All Aspects}

Among the mean values of all aspects, the performance expectancy is the maximum one, the second is condition facilitating, and the minimum is social influence. Please see "Table II". 
TABLE II. DESCRIPTIONS AND StATISTICS OF AlL ASPECTS

\begin{tabular}{llccll}
\hline S/N & Name of Aspects & Min. & $\begin{array}{c}\text { Max } \\
\cdot\end{array}$ & Mean & $\begin{array}{c}\text { Standard } \\
\text { Difference }\end{array}$ \\
\hline 1 & $\begin{array}{l}\text { Performance } \\
\text { Expectancy }\end{array}$ & 1.00 & 7.00 & 5.85 & .87 \\
2 & Effort Expectancy & 1.00 & 7.00 & 5.41 & 1.12 \\
3 & Condition & 1.00 & 7.00 & 5.51 & 1.00 \\
& Facilitating & 1.00 & 7.00 & 5.26 & 1.20 \\
4 & Social Influence & 1.00 & 7.00 & 5.47 & 1.13 \\
\hline
\end{tabular}

\section{Correlation Analysis 22}

Through the analysis on effort expectancy, social influence, performance expectancy, facilitating conditions, and person correlation of mobile guide system use intention, it is found that the four aspects and intention of use are of moderate correlation, which, from big to small, is social influence $(\mathrm{r}=.808)$, facilitating conditions $(\mathrm{r}=.658)$, performance expectancy $(\mathrm{r}=.620)$, and effort expectancy $(\mathrm{r}=.591)$. Correlation coefficients are as shown in "Table III".
TABLE III. CORRELATION ANALYSIS FORM

\begin{tabular}{|c|c|c|c|c|c|}
\hline & $\begin{array}{c}\text { Performance } \\
\text { expectancy }\end{array}$ & $\begin{array}{c}\text { Effort } \\
\text { expectancy }\end{array}$ & $\begin{array}{c}\text { Facilitating } \\
\text { conditions }\end{array}$ & $\begin{array}{c}\text { Social } \\
\text { influence }\end{array}$ & $\begin{array}{c}\text { Intention } \\
\text { of use }\end{array}$ \\
\hline $\begin{array}{l}\text { Performance } \\
\text { expectancy }\end{array}$ & e 1 & & & & \\
\hline $\begin{array}{l}\text { Effort } \\
\text { expectancy }\end{array}$ & $.660 * *$ & 1 & & & \\
\hline $\begin{array}{l}\text { Facilitating } \\
\text { conditions }\end{array}$ & $.601 * *$ & $.679 * *$ & 1 & & \\
\hline $\begin{array}{l}\text { Social } \\
\text { influence }\end{array}$ & $.569 * *$ & $.675^{* *} *$ & $.688 * *$ & 1 & $*$ \\
\hline $\begin{array}{l}\text { Intention } \\
\text { use }\end{array}$ & of. $620 * *$ & $.591 * *$ & $.658 * *$ & $.807 * *$ & 1 \\
\hline
\end{tabular}

**. When the significance level is 0.01 (double-tail), the correlation is significant.

\section{E. Multiple Regression Analysis}

Multiple regression analysis: the multiple regression analysis is adopted for discussing the effect of performance expectancy, effort expectancy and social influence on the intention of use (see "Table IV"). Based on the regression analysis, the Adjust R2 of performance expectancy, effort expectancy and social influence to intention of use is 0.688 , and the VIF value is smaller than 5, which means no collinearity exists.

TABLE IV. Multiple REgRESSION ANALYSis AbSTRACT

\begin{tabular}{lcccccccc}
\hline $\begin{array}{l}\text { Independent } \\
\text { Variable }\end{array}$ & R & R2 & $\begin{array}{c}\text { Adjust } \\
\text { R2 }\end{array}$ & $\begin{array}{c}\text { R2 Squared } \\
\text { Change }\end{array}$ & F Value & $\begin{array}{c}\text { Original } \\
\text { Regression } \\
\text { Coefficient }\end{array}$ & $\begin{array}{c}\text { Standard } \\
\text { Regression } \\
\text { Coefficient }\end{array}$ \\
\hline $\begin{array}{l}\text { Constants } \\
\text { Social influence }\end{array}$ & .807 & .652 & .651 & .652 & 591.310 & .366 & .631 & .129 \\
$\begin{array}{l}\text { Performance } \\
\text { expectancy }\end{array}$ & .831 & .690 & .688 & .038 & 38.679 & .306 & .000 \\
\hline
\end{tabular}

Dependent variable: intention of use

It can be seen from the estimation value part of $\beta$ in"Table IV"that, social influence $(0.631, \mathrm{p}=.000)$ and performance expectancy $(\beta=0.306, p=.000)$ have positive effect on the intention of use, among which, social influence $\beta$ value is the maximum, which means social influence has maximum influence on the intention of using guide system.

\section{F. Practical Use}

The number and percentage of persons using mobile travel guide system are shown in "Table V".

TABLE V. Analysis on Practical Use of Healthe Mobile TRAVEL GUIDE SYSTEM

\begin{tabular}{|c|c|c|c|c|}
\hline Item & Category & $\begin{array}{l}\text { Persons } \\
\text { Number }\end{array}$ & Percentage & $\begin{array}{c}\text { Accumulative } \\
\text { Percentage }\end{array}$ \\
\hline Practice Use & & 216 & 67.9 & \\
\hline \multirow[t]{3}{*}{ Times number } & Never Used & & & 67.9 \\
\hline & Used & 102 & 32.1 & 100.0 \\
\hline & Sum & 318 & 100.0 & \\
\hline
\end{tabular}

\section{FINDINGS AND SUGGESTIONS}

\section{A. Targeting for the Research Purpose and Issues, the Discussion Is Carried out As Follows.}

College students' performance expectancy, intention, and practical use of mobile guide system.

It can be seen from the mean value of the performance expectancy $(5.85 / 7=0.835)$ that, $83.5 \%$ college students confirm that the use of the automatic guide system could make them feel more convenient to look up the scenic site information; college students also pay attention to the enhancement of travel quality by using the automatic guide system. But the part intending to use the system only occupies $78.1 \%(5.47 / 7=0.781)$. This means that the intention to use is lower than the recognition of automatic guide system. This result is similar to the result of Chen Mingshu (2001) who points out that correct recognition of automatic guide system doesn't mean comparatively high consumption intention of automatic guide system. The amount of interviewees who actually used the guide system for healthy travel reaches 102 persons, occupying $32.1 \%$. The amount of interviewees who haven't used the guide system for healthy travel is 216 persons, occupying $67.9 \%$. It can be seen that it still needs further promotion in college students for using scientific and technical guide system. 


\section{B. Factors Affecting College Students' Intention of Using Mobile Guide System}

This research finds out that the factors affecting the intention of using the automatic guide system, from big to small, are respectively: social influence, performance expectancy, and effort expectancy. This means that when the important social relating person of the college student supports the mobile guide system, the college student's intention of using the system would be high, or else, the intention of use would be low. The second point is that if the students know clear about the importance and convenience of the mobile guide system, and the interface of the system is humanoriented, and the network speed is very fast, the intention to use is high. Therefore, the hypotheses 1,2 , and 3 set in this research are verified to be tenable.

\section{SUGGESTIONS}

\section{A. Suggestions for Government}

Popularization of network coverage is a vital factor. Therefore, the government shall accelerate the infrastructural construction of communication devices and equipment to enhance network coverage rate and transmission quality, continuously engage in construction of smart tourism city and smart scenic spots to encourage people to use the scientific guide system, expand the quality and quantity of scientific travel, and accelerate and promote the tourism to be the new economic growth under new normal economy.

\section{B. Suggestions for Mobile Industry Personnel}

$83.5 \%$ students recognize the mobile guide system performance, but only $78.1 \%(5.47 / 7=0.781)$ students intend to use the guide system. It can be seen that the intention to use is lower than the recognition of the mobile guide system. Therefore, the industrial personnel still have promotion space.

Affecting degree of intention of use: social influence > performance expectancy. Social influence refers to the degree that the users praise the use of the interviewees who they feel important, including implicated reputation importance. Therefore, the industry personnel shall not ignore the influence of the group. Performance expectancy: mastering real-time information makes me feel easier and more excellent travel quality. Therefore, surfing on line function and speed and information completion are both the things to be considered.

Effort expectancy refers to the easiness of use, including easy-to-use recognition, complexity, and easy-to-use, which can deeply affect students' intention of use. Therefore, humanoriented cell phone operating and easy search are both the elements that the industry personnel shall care. In this research, this factor hasn't been selected into the reverse deduction model. That may be because of the reason that the college students have already become skillful in using cell phone, so that effort expectancy is not an important affecting factor anymore.

\section{Suggestion for Academic Field}

Non-random sampling is adopted in this research which may result in deviation or unable to spread to all users. It is suggested that learners having interest may adopt random sampling to reduce deviation. Besides, the multiple regression analysis method is adopted in this research. It is suggested that the structural equation model can be adopted to inspect to make it more clear about the causal relationship of all related variables.

\section{ACKNOWLEGEMENT}

It should express the deepest gratitude to Fujian Education Science "12th Five-year Plan" and 2015 Cross-Straits Occupational Education Research Subject with serial number FJJKHX15-053 and name of Evaluation of Fujian and Taiwan College Students Acceptance and Intention of Using the Tourism Ecological Guide System.

\section{REFERENCES}

[1] Huang Sufang (2001), Study on Relative Factors Affecting User's Intention to Use [Internet Recruitment] - Scientific Acceptance Model Application, Chaoyang University of Technology Enterprise Management Institute, Master's Degree Dissertation

[2] Cai Bingru (2004), Study on Factors Affecting Life Insurance Personnel Using Mobile Life Insurance System, SHU-TE UNIVERSITY Information Management Department, Master's Degree Dissertation.

[3] Lai Meijiao, Xu Suzhen, Cai Wude (2006), Research on Evaluation of Medical Beauty Facing Feasibility by UTAUT, Commerce Modernization Magazine, Volume 3, Period 3, 241-249

[4] Lai Meijiao, Cai Wude (2006), Research on Intention and Behavior of Students' Using Health Inspection at Their Own Expense, Chinese Medicine Humanity Journal, 13

[5] Fujian Provincial Tourism Bureau Office Zhao Hongwei, 2015-05-29 Policy Explanation for Fujian People's Government Implementation Suggestion on Further Deepening Tourism Reform and Development, 2016-05-15, http://www.fjta.gov.cn/ar/20150528000302.htm

[6] Ajzen, I. \& Fishbein, M., (1980). Understanding Attitudes and Predicting Social Behavior. Prentice-Hall, Englewood Cliffs, NJ.

[7] Davis, F. D. (1989) . Perceived Usefulness, Perceived Ease of Use, and User Acceptance of Information Technology. MIS Quarterly13 (3), pp. 319-339.

[8] Davis, F. D., Bagozzi, R. P., and Warshaw, P. R. ( 1989 ) .User Acceptance of Computer Technology : A Comparison of Two Theoretical Models. Management Science, 35(8), pp. 982-1002.

[9] Venkatesh, V. ( 2000 ) . Determinants of Perceived Ease of Use: Integrating Perceived Behavioral Control, Computer Anxiety and Enjoyment into the Technology Acceptance Model. Information Systems Research. 11 (4), pp. 342-365.

[10] Venkatesh, V., and Davis, F. D. (2000). A Theoretical Extension of the Technology Acceptance Model: Four Longitudinal Field Studies. Management Science, 45 (2), pp. 186-204.

[11] Venkatesh, V., M.G., Morris, G. B. Davis and F. D. Davis. (2003) User Acceptance of Information Technology: Toward A Unified View. MIS Quarterly, 27, 4 pp.425-478.

[12] Venkatesh, V., Morris, M. G., and Ackerman, P. L. ( 2000 ) . A Longitudinal Field Investigation of Gender Differences in Individual Technology Adoption Decision Making Processes. Organizational Behavior and Human Decision Processes 83 (1), pp. 33-60. 